\title{
Gábor Pusztai
}

\section{Onze man in Nagasaki}

\author{
De gefantaseerde diplomatieke dienst van András Jelky \\ in Japan
}

\begin{abstract}
The history of András Jelky was published in German in 1779 in Vienna and in Prague. Jelky was employed by the VOC and had sailed to the Dutch East Indies, had had adventures there and built a career. According to the book from 1779, he also worked as an emissary in Japan. In this article I will discuss the topic of the Dutch-Japanese relations in the 16th to 19th century and the potential role of Jelky.

Keywords: András Jelky, Dutch-Indies, VOC, Japan
\end{abstract}

In de tweede helft van de achttiende eeuw waren de meeste werknemers van de VOC buitenlanders. ${ }^{1}$ Onder deze 51.800 buitenlanders was er ook een aantal Hongaren. In totaal waren er 118 Hongaarse werknemers van de VOC, ${ }^{2}$ waarvan we maar van één enkele een gedetailleerde levensloop kennen. Deze ene werknemer is de Hongaarse kleermaker uit Baja die in de literatuur als András Jelky bekend is geworden.

In 1779 verscheen bij uitgever Johan Georg Weingand in Wenen een boekje met de titel: Geschichte des Herrn Andreas Jelky eines gebohrnen Ungars, welcher nach ausgestandenen vielen unglücklichen Zufällen, Schiffbrüchen, Sklaverey und Lebensgefahren unter den Wilden, endlich zu Batavia zu ansehnlichen Ehrenstellen gelangen ist. Volgens dit verhaal werd Jelky in het Zuid-Hongaarse stadje Baja geboren en ging als kleermakersleerling naar Wenen om zijn ambacht beter te leren. Vandaar vertrok hij naar Parijs, maar heeft de Franse hoofdstad nooit bereikt. Hij werd namelijk in Rotterdam geronseld voor de VOC en kwam op een 
schip terecht dat naar Oost-Indië voer. Nog op het Kanaal kwam het schip in zwaar weer terecht. De bliksem sloeg in de mast, waardoor er brand ontstond. Sommigen raakten in paniek en sprongen overboord, ook Jelky. De volgende dag werd hij door Engelse vissers uit het water gehaald en werd enkele dagen door hen verzorgd. Per ongeluk raakte ook een ander Nederlands schip aan de Engelse kust verzeild en Jelky meldde zich terstond bij de schipper en vroeg of hij mee mocht. Hij werd aan boord genomen, maar het schip voer niet naar Java, maar naar Suriname. Terug in Europa ging hij in Lissabon aan land en van hier vertrok Jelky weer richting Azië. Na verschillende avonturen zoals schipbreuk, een gevecht met zeerovers, slavernij in Noord-Afrika, een vlucht uit de slavernij enz. kwam hij uiteindelijk in 1758 in Batavia aan en werd inwoner van de stad. Hij mocht zijn kleermakerszaak openen, kon veel geld verdienen en trouwde. Vanwege een misverstand viel hij uit de gratie bij zijn belangrijkste beschermheer, Petrus Adrianus van der Parra, en moest weer het leger in. Vanwege een opstand op Ceylon moest hij als militair van de VOC naar zee, om de onlusten op het eiland tot bedaren te brengen. $\mathrm{Na}$ Ceylon volgden gevechtshandelingen op Ambon, Banda en Ternate. Aanvankelijk met succes, maar hij belandde desondanks in de handen van kannibalen en kon op het nippertje ontkomen dankzij de hulp van een schone inheemse vrouw. Jelky woonde samen met haar en hun twee bediendes op een verlaten plek. Helaas stierf de inheemse vrouw van Jelky al na een jaar. Hij kwam later met de hulp van een Chinese kapitein van een jonk weer naar Batavia. Hier werd hij door de inmiddels gouverneur-generaal geworden Van der Parra met veel eerbetoon ontvangen, en werd met een hoge rang in de burgerwacht en verschillende ambten beloond. Zo werd hij in opdracht van de VOC ook gezant in Japan. Na de dood van zijn vrouw vertrok hij in 1776 naar Europa en kwam via Amsterdam naar Wenen, waar hij zelfs door keizerin Maria Theresia en haar zoon Jozef werd ontvangen. Tot zover het verhaal van Jelky volgens het boekje uit 1779 .

\section{Jelky's avonturen op schrift}

De geschiedenis van András Jelky moet erg populair zijn geweest, want het werd maar liefst binnen één jaar drie keer herdrukt. Twee drukken verschenen in Wenen ${ }^{4}$ en eentje in Praag. ${ }^{5} \mathrm{Bij}$ de eerste twee uitgaven werd de auteur niet vermeld, maar bij de derde druk zien we de naam 
Anton Ferdinand von Geissau (1746-1809) vermeld als schrijver. ${ }^{6}$ Het is waarschijnlijk dat Jelky zijn verhaal aan hem of aan iemand anders heeft verteld en niet zelf op papier heeft gezet. $^{7}$ De eerste druk bestaat uit twintig, de tweede uit zestien genummerde pagina's en vertelt de avonturen van Jelky van Baja tot Batavia en tenslotte zijn aankomst in Wenen. De vierde druk verscheen met andere verhalen en anekdoten in één bundel in 1784 in Ofen en Pressburg ${ }^{8}$ dat wil zeggen, in nu Boeda en Pozsony/Bratislava. In deze uitgave werd het levensverhaal van Jelky aangevuld met de gebeurtenissen van zijn vijf laatste levensjaren. ${ }^{9}$ In het Hongaars werd het boekje pas in 1791 uitgegeven, in de West-Hongaarse stad Győr, onder de titel Jelki Andrásnak, egy született magyarnak történetei [De verhalen van András Jelky, een geboren Hongaar]. ${ }^{10}$ Het negenentwintig pagina's tellende boekje is een letterlijke vertaling van de Duitse uitgave.

Het verhaal van Jelky is dankzij schrijver, journalist, kunsthistoricus en criticus Lajos Hevesi (1843-1910) bewaard gebleven. In 1872 heeft hij het korte levensverhaal van Jelky uit 1791 tot een roman omgewerkt met de titel Jelky András kalandjai. Zijn boek kent tot op heden diverse bewerkingen en herdrukken. In alle varianten van het verhaal vinden we de passage over Jelky's Japanse diplomatieke missie die hij in dienst van de Verenigde Oostindische Compagnie zou hebben uitgevoerd.

\section{Als diplomaat in Japan?}

In de eerste druk, Geschichte des Herrn Andreas Jelky, eines gebohrnen Ungarns (Wien, 1779) kunnen we op pagina 18 over de missie in Japan het volgende lezen: 'Sein Erstes Geschäft war die Gesandtschaft nach Japonien, allwo er durch kostbare Geschenke es dahin brachte, dass dem Ansuchen der holländischen Republick geneigt willfahret wurde.' ${ }^{11}$ In de Hongaarse vertaling vindt de lezer dezelfde tekst. De Hongaarse vertaler István Sándor (1750-1815) die ook als schrijver en bibliograaf bekend stond en de auteur van de eerste Hongaarse nationale bibliografie Het Hongaarse Boekenhuis (Magyar Könyvesház) (1803) was, schreef op pagina 24 van het boekje uit 1791 het volgende: 'Zijn eerste opdracht van belang was zijn gezantschap naar Japan, waar het hem door kostbare geschenken lukte de belangen van de Republiek te behartigen. ${ }^{, 12}$

In het Duits en ook in het Hongaars waren deze uitspraken buitengewoon vaag. Om wat voor belangen ging het? Waarom moest hij kostbare 
geschenken meenemen en voor wie? Deze vragen blijven in de tekst geheel onbeantwoord. De lezer moet met deze ene zin over Japan en de Nederlanders aldaar genoegen nemen. Latere schrijvers, die het verhaal van Jelky op papier hebben gezet, voelden aan dat deze informatie wat mager was en probeerden het aan te vullen of aan te dikken, maar meestal ging het vanwege het gebrek aan historische kennis helemaal mis.

Het schrijversduo Lászlóné Konrády en László Povázsay schreef in 1947 een nieuwe versie van de avonturen van Jelky met de titel De avonturen van András Jelky (Jelky András viszontagságai). Op pagina 30 vinden we de volgende passage: 'Het eerst werd hij (Jelky) met de opdracht naar Japan gezonden, omdat de Japanse regering meer schepen naar Batavia moest sturen. Met geld en handigheid heeft hij zijn doel bereikt. $^{, 13}$

In deze periode (in de tweede helft van de 18de eeuw) voeren er überhaupt geen Japanse schepen naar Batavia. Het was voor Japanse onderdanen verboden Japan te verlaten. Japan heeft zich in die tijd geheel willen isoleren van de rest van de wereld. Slechts de Nederlanders mochten naar Japan varen.

Het verhaal van Jelky is in Hongarije vooral bekend vanwege de jeugdroman van Lajos Hevesi (oorspronkelijk Lajos Lőwy) (1843-1910). In 1872 verscheen De avonturen van András Jelky, de jongen uit Baja, in vijf en half continenten. Gebaseerd op historische bronnen. Hongaars volksboek bijzonder voor de rijpere jeugd (Jelky András bajai fiú rendkivüli kalandjai ötödfél világrészben. Történeti kutforrások alapján. Magyar népkönyv különös tekintettel a serdültebb ifjuságra). Het boek werd erg populair en werd herhaaldelijk herdrukt. In de zesde herdruk, een uitgave uit 1904, staat het volgende over de diplomatieke missie van Jelky in Japan:

Eerst werd Jelky tot bijzondere ambassadeur aan het hof van de Japanse keizer benoemd. Dat was de eerste keer in de geschiedenis van Japan en Nederland dat een Nederlandse ambassadeur naar Japan ging. In deze tijd was het enorme eilandenrijk van Oost-Azië afgesloten voor de Europeanen. Vreemdelingen mochten het land niet in, en de bewoners waren net zo vijandig tegenover vreemdelingen als de regering. Het leek erop dat men met Japan überhaupt geen zakelijke relatie kon aanknopen. Maar de Nederlandse regering hechtte er veel waarde aan dat de enorme Japanse markt voor de Nederlandse handel zou worden geopend. Daarom werd de ervaren en bekwame András Jelky als ambassadeur naar het hof van de Japanse keizer gestuurd. Hij introduceerde zich in de hoofdstad 
Jeddo met de glans en glorie die zijn ambt verlangde. De vorst en de regering werden van tevoren ingelicht over de rijke ervaringen van deze man en Jelky werd daarom met veel eerbetoon ontvangen. Een deel van de lijfwachten van de keizer werd onder hem gesteld, er werden ter ere van hem feestelijke diners gehouden, vuurwerk afgeschoten en keizerlijke jachten georganiseerd, de meest verschillende evenementen wisselden zich af, tijger- en olifantsgevechten werden gehouden, de hofdichters moesten nieuwe toneelstukken schrijven die de acteurs met veel inleving opvoerden ter ere van de Nederlandse gezant enz, enz. In Japan was nooit tevoren een dergelijk spektakel te beleven. Het doel was desondanks moeilijk te bereiken. De regering was niet bereid van de eeuwenoude isolatiepolitiek af te zien. Vergadering volgde op vergadering, audiëntie op audiëntie, en er vlogen maanden voorbij. Maar het gaf een grote voldoening toen er toch resultaat kon worden geboekt. Jelky kon de oude tegenstellingen bestrijden en de afkeer naast zich neerleggen. Toen hij door de keizer zelf en de ministers met geschenken beladen Japan heeft verlaten, had hij al het contract met Japan op zak, getekend door de keizer zelf en met het stempel van het Japanse Rijk erop. Op het contract was de vertegenwoordiger van het machtige Nederland vermeld, in de vorm van slechts een gewone naam: András Jelky. Wat anderen vaak hebben geprobeerd, maar wat hun nooit gelukt was, dat was Jelky wel gelukt. Hij kon het enorme rijk van Japan openen voor de Europese handel. ${ }^{14}$

De roman van Hevesi verscheen ook in 1955, maar in herwerkte vorm, door János Czibor. Naast grammaticale herzieningen waren er ook inhoudelijke veranderingen in de tekst:

De Nederlandse regering heeft zijn bekwame diplomaat naar Japan gezonden, met de opdracht dat hij diplomatieke- en handelscontacten moest aanleggen tussen Nederland en Japan. Dit moest ervoor zorgen dat het enorme eilandenrijk van Oost-Azië deel werd van het internationale handelsnetwerk. Deze opdracht was zeker niet makkelijk. In die tijd was Japan al lang geïsoleerd van de Europeanen. Vreemdelingen mochten de grens niet passeren, zelfs nieuws sijpelde nauwelijks door uit deze geheimzinnige wereld. De Japanse keizer, de mikado, en zijn regering bekeken alle Europese toenaderingen met argwaan. Maar de Nederlandse regering wist te bereiken dat de Japanners haar gezant wilden ontvangen. Deze gezant was András Jelky. Toen het schip van Jelky na maanden de Japanse kust verliet, en hij het gesloten contract voor zich uitrolde, kon hij zelf ook amper geloven dat naast de statige handtekening van de mikado zijn Hongaarse naam stond omdat hij het machtige Koninkrijk (sic) van Nederland heeft vertegenwoordigd. Het was een enorm wapen- 
feit omdat velen voor hem tevergeefs geprobeerd hebben dit doel te bereiken. Maar hem was het gelukt en terecht werd zijn naam in de hele wereld geëerd in diplomatieke- en handelskringen. ${ }^{15}$

In de literatuur werd de legende van de diplomatieke missie van Jelky in Japan dus gevestigd. Het verhaal is met de nodige nationale trots opgesmukt en uitgebreid en dit heeft zich ook een weg gebaand in de wetenschappelijke wereld. De geograaf en wetenschapshistoricus János Kubassek schrijft in zijn artikel De globetrotter kleermakersgezel (A világjáró szabólegény) uit 2014 dat Jelky '(...) een officiële delegatie leidde naar Japan (...)., 16

De vraag rijst natuurlijk in hoeverre de magere mededeling uit 1779 juist is, dat Jelky in Nederlandse diplomatieke dienst naar Japan werd gezonden. De bovengenoemde citaten van Hevesi zitten vol met gaten. Nederland was toen nog een republiek en geen koninkrijk, buitenlanders onderhandelden in Japan nooit met de keizer, maar met de shogun en de Nederlands-Japanse handelscontacten bestonden toen al meer dan 150 jaar. En de zogenaamde isolatiepolitiek moeten we ook met een korreltje zout nemen. In het volgende deel van dit artikel zal ik de NederlandsJapanse contacten van de $17^{\text {de }}$ en $18^{\text {de }}$ eeuw behandelen en probeer ik het verhaal van Jelky in dit netwerk te plaatsen.

\section{Nederlanders in Japan}

Eén van de zogenaamde voorcompagnieën was de Magelhaense Compagnie $^{17}$ die op 27 juni 1598 vijf schepen uitzond: de Liefde (de vroegere Erasmus), de Hoop, de Geloof, de Trouwe en de Blije Boodschap. De schepen vertrokken van Goeree onder leiding van Jaques Mahu. Na zijn dood werd Simon de Cordes de schipper. De bedoeling was dat ze via de Straat Magellaan naar Azië zouden varen. Onderweg liep echter van alles mis. De Hoop verging in de oceaan, de bemanning van de Trouwe werd door de Portugezen neergesabeld of gevangengenomen, de Blijde Boodschap werd door de Spanjaarden in de haven van Valparaiso in beslag genomen, en de Geloof moest omkeren omdat de bemanning aan het muiten was geslagen en kwam in juni 1600 weer in Nederland aan. De Liefde kwam op 19 april 1600 aan de Japanse kust aan, bij het eiland Kioesjoe, in de Oesoeki-baai. Toen waren aan boord nog slechts 24 van de bemanning in leven. 


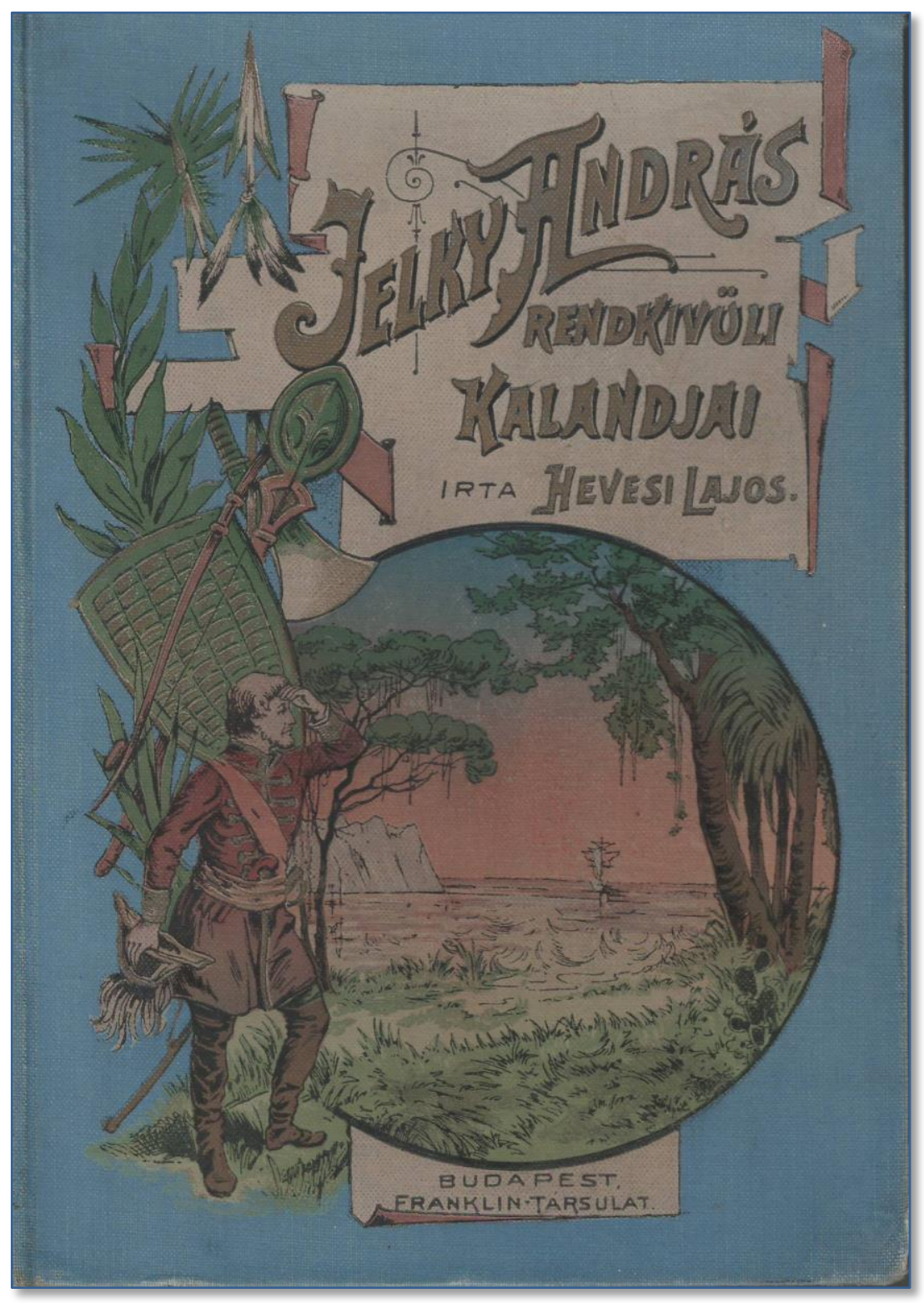

De uitgave van de Franklin-Társulat uit 1908. 
Na de dood van de schipper nam Jacob Janszoon Quackernaeck de leiding over. Het schip en zijn lading werden in beslag genomen door de landheer, en één van de machtigste krijgsheren van toen, Tokoegawa Ijasoe (1543-1616), die later ook shogun werd.

De overlevenden van de Liefde waren niet de eerste Europeanen in Japan. Japan was al eeuwen hiervoor bekend in Europa door de verhalen van Marco Polo (1254-1324), die vooral de enorme rijkdom van Zipangu (zo werd Japan door hem genoemd) beschreven heeft. ${ }^{18}$ Columbus was ook op zoek naar de met goud gedekte daken van de Japanse kastelen. Toen hij op 24 oktober 1492 naar Cuba vertrok omdat hij van de inheemsen hoorde dat op dat eiland veel goud zou zijn, dacht hij dat Cuba Japan was. ${ }^{19}$

Columbus zette nooit voet aan wal in Japan, maar vijftig jaar later, op 23 juni 1543, kwamen drie Portugese schipbreukelingen aan boord van een Chinese jonk aan de kust van Japan, in Tanagasjima, aan. Eén van deze Portugezen was Fernaõ Mendes Pinto. ${ }^{20} \mathrm{Na}$ de schipbreukelingen kwamen in 1549 Portugese Jezuïeten naar Japan, onder leiding van Franciscus Xavér. Onder zijn leiding begon het missiewerk in Hirado, Jamagutsji, Kito en Foenai. De Jezuïeten hebben rond 1570 ca. 130.000 Japanners bekeerd tot het katholicisme. Tien jaar later was het aantal der bekeerlingen 170.000 , rond 1590 waren al 200.000 van de toen 25-27 miljoen Japanners christen geworden. ${ }^{21}$ De Jezuïeten deden niet alleen aan missie, maar hielden ook de zijdehandel met China in handen. ${ }^{22}$ De haven van Nagasaki, waar de zijdehandel grotendeels plaatsvond, stond aan het einde van de $16^{\text {de }}$ eeuw onder de leiding van de Jezuïeten. ${ }^{23}$ In 1587 nam de situatie echter een voor de Portugezen ongunstige wending. In dat jaar kwamen Spaanse Franciscanen en Dominicanen naar Japan. Zij wilden vooral de bevolking bekeren en toonden weinig begrip voor de traditionele Japanse waarden en normen zoals het shintoïsme en boeddhisme. Volgens hen moesten de heidenen desnoods met geweld bekeerd worden zodat het enige ware geloof, het katholicisme, in Japan kon overheersen. ${ }^{24}$ Dat zorgde voor de nodige spanningen tussen de Jezuïeten aan de ene kant en de Franciscanen en Dominicanen aan de andere kant, respectievelijk tussen Portugezen en Spanjaarden. Deze conflicten bekeken de Japanners met steeds groeiende argwaan. De feitelijke bestuurder van het land, Tojotomi Hidejosji, meende dat de Europeanen niet alleen vanwege de godsdienst naar Japan kwamen, maar eigenlijk spionnen waren die een grote invasie aan het voorbereiden waren. In dit vermoeden werd hij gesterkt door het zogenaamde San 
Felipe incident. Het Spaanse schip, de San Felipe, liep in oktober 1596 op de klippen voor de kust van Japan. Men wilde van Manila naar Acapulco, maar werd door een tyfoon gegrepen en het schip dreef naar Japan af. De navigator van het schip, Francisco de Olandia, verklaarde met behulp van een wereldkaart voor de Japanse autoriteiten dat de Spaanse koning de halve wereld onder zijn gezag had en legde de plaatselijke daimjo, Hasjita Nagamori, uit dat bij expansie de eerste golf altijd de missionarissen zijn die straks door de conquistadores gevolgd worden. ${ }^{25}$ Nagamori meldde het nieuws onmiddellijk aan Hidejosji die zijn vermoeden hierin bevestigd zag. Waarschijnlijk als reactie hierop werden op 5 februari 1597 in Nagasaki 26 christenen (6 Spaanse Franciscanen, 3 Japanse Jezuïeten en 17 Japanse christenen) geëxecuteerd (gekruisigd). ${ }^{26} \mathrm{Na}$ de dood van Hidejosji, één jaar later, werd de anti-christelijke houding van de Japanners milder. Na een bloedige slag bij Sekigahara op 20-21 oktober 1600, werd Tokoegawa Ijasoe de nieuwe leider van het land. Op dat moment waren de overlevenden van de bemanning van de Liefde al een half jaar in Japan. De Engelse stuurman van de Liefde, William Adams, maakte grote indruk op Tokoegawa. Adams kreeg een landgoed in Mioera, een huis in Edo en werd later ook samoerai met de rang van hatamoto (vaandrig). ${ }^{27}$ Ook de Nederlanders Jan Joosten van Lodensteijn en Melchior van Sandvoort kregen gunsten van de shogun en mochten zich als handelaar in Edo vestigen. ${ }^{28}$

In 1602 werd de VOC opgericht. De Nederlandse expansie overzee richtte zich niet alleen op de handel, maar stond ook in het teken van de Tachtigjarige Oorlog tegen de Spanjaarden en Portugezen. Zo veel mogelijk schade toebrengen aan de vijand (ter zee, ter land, in Azië, Afrika of in Amerika) was één van de belangrijkste doelen. Hiertoe werd in 1603 in Patani een factorij opgericht. Het nieuws bereikte in 1604 Japan en Tokoegawa wilde contact opnemen met de vertegenwoordigers van de VOC. Victor Sprinckel, de leider van de VOC-factorij, hoorde in 1605 van Quaeckernaeck en van Van Santvoort dat de shogun bereid was een handelscontract met de Nederlanders te sluiten. In 1608 werd Van Santvoort naar Japan teruggestuurd om de komst van de Nederlandse schepen voor te bereiden. De eerste twee schepen, de Roode Leeuw met Pijlen en de Griffioen, kwamen in juli 1609 in Hirado aan. Tokoegawa gaf op 24 augustus 1609 de Nederlanders praktisch onbeperkt handelsrecht in Japan. $^{29}$ 
De Nederlanders besloten op 20 september 1609 in Hirado een factorij op te richten waarvan het opperhoofd Jacques Specx werd. Hiermee waren officieel de handels- en diplomatieke contacten tussen Japan en Nederland tot stand gebracht. Het opperhoofd was niet alleen voor de handel, maar ook voor diplomatieke betrekkingen en militaire aangelegenheden verantwoordelijk. ${ }^{30}$

In 1613 kwamen ook de Engelsen naar Japan. Aan boord van de Clove arriveerde kapitein John Saris (1580-1643) op 12 juni 1613 in Hirado en de Engelsen kregen binnen korte tijd ook een handelsvergunning van de shogun. ${ }^{31}$ Tokoegawa was voor de handel met de Nederlanders en de Engelsen, maar keek met argusogen naar de christelijke missie in zijn land. De uitoefening van de christelijke godsdienst werd steeds sterker beperkt en in 1613 verboden. Tokoegawa overleed in 1616, Adams vier jaar later, in 1620.

De Nederlanders en de Engelsen sloten een bondgenootschap tegen de gemeenschappelijke vijand en concurrentie, dus tegen de Spanjaarden en de Portugezen. Ze vielen op de zee tussen Manila en Japan Spaanse en Portugese schepen aan en roofden ze leeg. De buit probeerden ze in Japan te verkopen als handelswaar. De Nederlandse handelswaar die tussen 1615 en 1621 op de Japanse markt werd gebracht, bestond voor 60-90\% uit soortgelijke geroofde goederen. ${ }^{32}$ De Japanners probeerden in 1621 de activiteiten van de Nederlands-Engelse defensievloot aan banden te leggen. De Engelsen hadden hierna weinig profijt van hun aanwezigheid in Japan en verlieten in 1623 het land. ${ }^{33}$ Eén van de concurrenten van de Nederlanders verliet dus vrijwillig het veld. De Spaanse, Portugese, Chinese en Japanse handelaren bleven voorlopig.

De volgende shogun, Tokoegawa Yemicu (1603-1651), nam in 1624 anti-christelijke maatregelen om de missieactiviteiten aan banden te leggen. In verband hiermee werd het de Spanjaarden en Portugezen verboden voet aan wal te zetten in Japan. In 1636 werden alle mestiezen met hun Japanse moeder het land uitgezet. ${ }^{34}$ Yemicus vijandige houding tegenover christenen was meer dan duidelijk. Hij wilde dat het christendom uit Japan verdween en dat het shintoïsme en het boeddhisme weer de enige religie werden. ${ }^{35}$

De Nederlands-Japanse betrekkingen werden nog door enkele gebeurtenissen op de proef gesteld, zoals het Nuyts-incident ${ }^{36}$ en de opstand van Simbara. $^{37}$ Maar er waren steeds minder concurrenten. Vanaf 1639 mochten van de shogun geen Portugezen meer Japan betreden. Vanaf 1635 mochten Japanners Japan niet meer verlaten en dat gold ook voor de 
handelaars. ${ }^{38}$ Van de handelsconcurrenten bleven dus alleen de Chinezen over.

Voor de Nederlanders leek het erop dat de zaken in orde waren. De concurrentie werd heel wat minder, de handel bloeide, er werd veel geld verdiend. In 1640 kwam Inoue Masasjige in opdracht van de shogun naar Hirado om de Nederlandse factorij te inspecteren en zag aan de gevel van een nieuw gebouw het opschrift 'Anno Domini 1639' staan. ${ }^{39}$ De Japanner ontstak in woede omdat hij het opschrift als onverhulde christelijke propaganda zag. Er werd verordend alle gebouwen onmiddellijk te slopen, voortaan mochten de opperhoofden maximaal één jaar in Japan blijven $^{40}$ en de Nederlanders moesten in het volgende jaar, in 1641, Hirado verlaten en naar Desjima verhuizen, naar een kunstmatig eilandje in de baai van Nagasaki. Het personeel van de factorij bestond uit 10-20 personen. De schepen kwamen in augustus en vertrokken weer in oktober. In deze periode was het druk op Desjima, maar voor de rest was het vooral saai. Alleen de hofreis naar de shogun in Edo elk jaar (tot 1790 elk jaar, hierna tot 1850 om de vijf jaar) zorgde voor afwisseling (het betekende $2000 \mathrm{~km}$ en drie maanden reizen). Bij deze gelegenheden werden de geschenken (die de shogun op een wenslijst van tevoren meedeelde) gepresenteerd. Onder andere Arabische paarden, kamelen, windhonden, geweren, kanonnen, verrekijkers en boeken werden overhandigd in de hoop dat de shogun het handelscontract met de Nederlanders zou verlengen. ${ }^{41}$ De uitoefening van het christelijke geloof was streng verboden. ${ }^{42}$ Wapens mocht alleen het opperhoofd dragen. ${ }^{43}$ Het leren van de Japanse taal was ook verboden voor de Nederlanders. ${ }^{44}$ De handel bloeide: tussen 1651 en 1671 had de VOC het meeste profijt van de handel met Japan. In die tijd kwamen elk jaar zeven schepen naar Nagasaki. ${ }^{45}$ Tussen 1642 en 1660 maakte de VOC 12 miljoen gulden winst dankzij de factorij op Desjima. ${ }^{46}$ Hierna werd het steeds minder. De Japanners probeerden de uitvoer en ook de invoer aan banden te leggen. In 1720 betekende de handel met Japan voor de VOC $39 \%$ verlies. $^{47}$ Vanaf 1715 kwamen per jaar slechts twee schepen naar Desjima, ${ }^{48}$ vanaf 1790 slechts één. ${ }^{49}$ Vanaf 1768 leed de VOC in Japan alleen maar verlies ${ }^{50}$ maar desondanks bleven de Nederlanders in Desjima als enige Europeanen. De factorij werd pas na het optreden van de Amerikaan Matthew C. Perry in 1853 en de daaropvolgende overeenkomst van Kanagawa in 1854, in februari 1860 opgeheven. De Nederlandse gezant verhuisde naar Edo, maar in Nagasaki bleef een consulaat bestaan. ${ }^{51}$ 


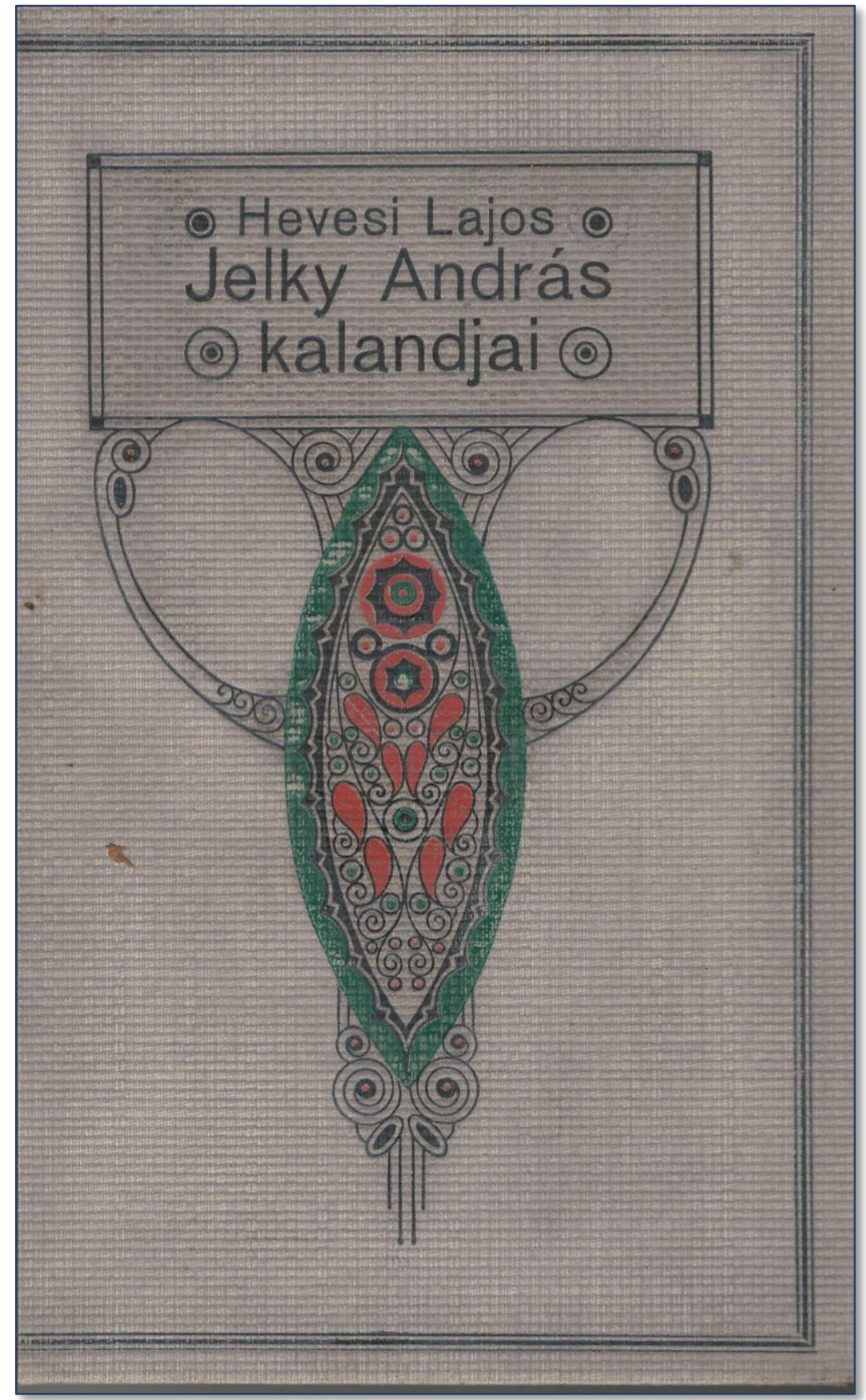

De uitgave van de avonturen van András Jelky uit 1911. 


\section{Conclusie}

Jelky (die volgens de monsterrol onder de naam Jan Andries Jelleke in dienst van de VOC diende) $)^{52}$ kwam op 22 april 1756 aan in Batavia met het schip Blijdorp. Twintig jaar later, op 26 oktober 1776, vertrok hij weer aan bord van de Popkensburg naar Nederland, waar hij op 18 juni 1777 afmonsterde. ${ }^{53}$ Kon hij in deze twintig jaar (1756-1776) een diplomatische missie naar Japan leiden? Zoals we hierboven zagen was dit de tijd van de langzame ondergang. De VOC leed in die tijd alleen maar verlies.

De carrière van Jelky in Batavia begon in 1764, negen jaar na zijn aankomst in Azië. Toen werd hij officier van de burgerij: eerst vaandrig ${ }^{54}$ en één jaar later luitenant. ${ }^{55}$ Vanaf 1765 was hij comissaris van huwelijkse en kleine gerichts-zaken. ${ }^{56}$ Vanaf 1767 werd hij heemraad van de stad. ${ }^{57}$ Dit ambt bleef hij tot 1775 bekleden. ${ }^{58}$ Hij had het dus erg druk met zijn administratieve baan in Batavia. Dat maakt het onwaarschijnlijk dat hij voor maanden of jaren naar Japan zou zijn gegaan. In de administratie van de VOC vind je zijn naam ook niet onder de naar Japan vertrokken of de van daar terugkerende VOC-dienaren.

Verder spreekt zijn vermeende verblijf ook tegen dat volgens de regels alleen Nederlanders in Japan mochten verblijven ${ }^{59}$ en Jelky was (ook volgens de VOC-monsterrol) een Hongaar ('ongaar bij de Stad Baja') ${ }^{60}$ dus hij had geen recht om op Desjima aan wal te gaan.

De Nederlandse diplomatieke belangen in Japan werden door het opperhoofd behartigd. Hij leidde de hofreis naar de shogun, hij was verantwoordelijk voor de onderhandelingen met de Japanners. Andere leden van het personeel van de factorij hadden dit recht niet. Dus als Jelky een diplomatieke missie heeft geleid in Japan, moest hij ook opperhoofd zijn. Maar zijn naam is op de lange lijst van de opperhoofden niet te vinden. ${ }^{61}$ Samenvattend kunnen we dus vaststellen dat de kans dat András Jelky, alias Jan Andries Jelleke, een Nederlandse diplomatieke missie in Japan zou hebben geleid, uiterst miniem is. Waarschijnlijk is hij nooit in het land van de rijzende zon geweest.

$$
* * *
$$


In de bijlage wordt het oorspronkelijke verhaal van Jelky in Nederlandse vertaling afgedrukt. De vertaling werd gemaakt op basis van het Duitse origineel uit 1779 . Het is naar ons weten de eerste keer dat deze tekst in het Nederlands verschijnt.

Noten

1 Rond 1770 was $80 \%$ van de soldaten en $50 \%$ van de zeelieden afkomstig uit het buitenland. Gaastra, De geschiedenis van de VOC. 81

2 Voor een volledige lijst zie: Pusztai \& Teszelszky, 'In de dienst van de VOC'. 25 108.

3 Over de naamvariaties Jelky, Jelleke, Jilka zie: Pusztai, 'Een Hongaarse VOC-dienaar'. 161-232.

4 Geschichte des Herrn Andreas Jelky eines gebohrnen Ungars. De Hongaarse vertaling van de Duitse tekst werd afgedrukt in Solymos, Ki volt Jelky András?, 9-17. De derde druk was Geissau, Etwas für alle zum Lesen im Frühling und Sommer.

5 Wunderbare Reise-Geschichte des Hrn. Andreas Jelky eines gebohrnen Ungars.

6 Anton Ferdinand von Geissau publiceerde graag over Hongarije. Naast het boek met het verhaal van Jelky schreef hij boeken over de belegering van Wenen ten tijde van Matthias Corvinus, en schreef ook over Móric Benyovszky. Geissau, Geschichte der Belagerung Wiens durch den König Mathias von Hungarn, in den Jahren 1484 und 1485. Geissau, Merkwürdige Aufmunterungsrede, welche Benjowsky gehalten für die Religion, den König und das Vaterland wider die Franzosen unverweilt die Waffen zu ergreifen.

7 Konrády \& Povázsay, Jelky András viszontagságai, 39.; Solymos, Ki volt Jelky András?, 6.

8 Geschichte des Herrn Andreas Jelky, eines gebohrnen Ungars, Nebst andern kurzweiligen Anekdoten.

9 Op de laatste pagina van het boekje werd vermeld dat Jelky in 1778 naar Boeda verhuisde, hertrouwde en dat uit dit huwelijk een zoon werd geboren. Het werd ook vermeld dat Jelky op 6 december 1783 aan tubercolose [Lungensucht] overleed. Solymos, Ki volt Jelky András?, 24.

10 Sándor, Jelki Andrásnak, egy született magyarnak történetei.

11 Geschichte des Herrn Andreas Jelky. 18.

12 'Első foglalatossága vala a' Japóniába való követsége, holott a' drága ajándékok által azt végzé, hogy a' Hollandiai Respublikának keresete bé-tellyesíttetett.' Sándor, Jelki Andrásnak, egy született magyarnak történetei. 24. De volledige tekst in het Nederlands, zie de bijlage van dit artikel.

13 'Legelőször Japánba küldték azzal a föladattal, hogy az ottani kormány minél több hajót irányítson Batávia felé. Pénzével és ügyességével célt ért.' Konrády \& Povázsay, Jelky András viszontagságai. 30.

14 'Először is a holland kormány rendkívüli követté nevezte ki a japán császár udvarába. Ilyen követségre ez volt a legelső példa Japán és Holland országok történetében. 
A kelet-ázsiai nagy sziget-császárság akkor hozzáférhetetlenül el volt még zárva az európaiak elől. Határait idegen át nem lépheté, a nép indulata ép oly ellenséges volt mint a kormányé, és úgy látszék, hogy ezen országgal egyáltalán nem lehet üzleti viszonyba lépni. A hollandi kormány azonban nagy fontosságot tulajdonított annak, hogy ezen óriási birodalom vására megnyittassék a hollandi kereskedelem számára, $\mathrm{s}$ ezért a bő tapasztalatú és világos elméjü Jelky Andrást küldte mint teljhatalmazott követet a japáni császárhoz. András Jeddóban, Japán fővárosában azzal a fénnyel lépett föl, melyet az általa képviselt állás tekintélye igényelt. Az uralkodó és a kormánykörök, jóelöre értesítve ezen ember rendkívüli élményeiről, a legnagyobb kitüntetéssel fogadták őt. A császári testőrség egy része kizárólag az ő rendelkezésére volt bocsátva, tiszteletére díszlakomák, tüzijátékok, udvari vadászatok, tigris- és elefántküzdelmek, szóval a legköltségesebb látványosságok váltakoztak, az udvari költőknek új színdarabokat kellett írniok, melyeket az udvari színészek nagy buzgalommal adtak elő a hollandi követ mulattatására stb. stb. Soha azelőtt Japánban ilyen nem történt. Mindazonáltal eleinte a cél nehezen látszott elérhetőnek. A kormány nemigen volt hajlandó az évszázadok óta követett elzárkózási politikájától egyszerre lemondani. A hosszadalmas tanácskozások és kihallgatások egymást érték, és hónap hónap után múlt. Mily elégtétel, midőn végre András államférfiúi ügyességének mégis sikerült az öröklött ellenszenveket és balítéleteket leküzdeni! Midőn, a császár és a miniszterek által a legdrágább ajándékokkal elhalmozva elhagyta a japáni fövárost, hogy Batáviába visszatérjen, zsebében volt a Holland és Japán közt kötött kereskedelmi szerződés eredeti okmánya, a császár által saját kezüleg aláirva és a japáni birodalom pecsétjével megerősítve. Jelky András: ezen egyszerű magyar név képviselte rajta a hatalmas, gazdag Hollandot. Ezzel nagy dolog sikerült Andrásnak. Amiben már annyi jeles fö hiába fáradozott, azt ő képes volt megvalósítani. Ö megnyitotta Japánt az európai kereskedelemnek.' Hevesi, Jelky András rendkívüli kalandjai. 294-295.

15 'A holland kormány a japán császár udvarába küldte leleményes követét, éspedig nem kisebb megbízással, mint hogy teremtsen diplomáciai és kereskedelmi összeköttetést Hollandia és Japán között és ezáltal kapcsolja be a világkereskedelmi hálózatba a nagy kelet-ázsiai szigetcsászárságot. Ez a megbízatás nem látszott könnyünek. A japáni birodalom akkor már hozzáférhetetlenül el volt zárva az európaiak elől, határait idegen semmiképpen sem léphette át, hírek is alig érkeztek ebből a rejtelmes világból, és a japáni császár, a mikádó és kormánya ellenségesen fogadott minden európai közeledést. Mégis hosszú fáradozások árán a holland kormánynak sikerült legalább annyit elérnie, hogy a császári udvar hajlandónak mutatkozott, fogadni és meghallgatni a követét. Ez a követ Jelky András volt. Amikor hosszú hónapok után András hajója elhagyta a császárság partjait, és ő kigöngyölte maga elé a megkötött kereskedelmi szerződés okmányát, bizony maga is hitetlenkedve nézte, hogy a mikádó kicifrázott névaláírása mellett az ő egyszerü magyar neve képviselte a másik felet, az akkor hatalmas Holland Királyságot. Nagy dicsőséget jelentett ez az okmány, hiszen amiben annyi kiváló ember hiába fáradozott, azt Jelky András sikeresen megvalósította, és nevét méltán emlegették a diplomácia és a kereskedelem köreiben mindenütt a világon.' Hevesi, Jelky András kalandjai. 298-299. 
16 'hivatalos küldöttséget vezetett Japánba' Kubassek, A világjáró szabólegény. 72.

17 De Magelhaense Compagnie of Rotterdamse Compagnie werd nog voor de VOC, in 1598 opgericht. De oprichters waren de uit Vlaanderen naar Rotterdam gevluchte handelaars Johan van der Veeken en Pieter van der Hage.

18 Polo, Marco Polo utazásai. 318.

19 Kolumbusz, Kolumbusz útinaplója. 20.

20 Kanai, Nederland en Japan 1602-1860. 194.

21 Túróczi, Szamurájok és "déli barbárok". 33.

22 De Chinezen hebben in de tijd van de Ming dynastie, in 1549, de zeehandel met Japan verboden vanwege de piratenactiviteit van de Japanse vako-schepen. Parmentier \& Laarhoven, De avonturen van een VOC-soldaat. 43.

23 Nagasaki werd in feite door de Japanse Omura aan de Jezuïeten cadeau gegeven. Kanai, Nederland en Japan 1602-1860. 197.; Túróczi, Szamurájok és „, déli barbárok”. 33.

24 Túróczi, Szamurájok és ,, déli barbárok”. 33.

25 Fish, The Manila-Acapulco Galleons. 497-498.; Murdoch, A History of Japan. 288289.; Laver, The Sakoku Edicts and the Politics of Tokugawa Hegemony, 60-61.; Newsom Crossley, The Desmarinases: Early Governors of the Spanish Philippines. 209.

26 Kanai, Nederland en Japan 1602-1860. 197.; Túróczi, Szamurájok és „, déli barbárok". 34.

27 De historische roman van James Clavell (1921-1994) met de titel Shogun uit 1975 beschrijft het verhaal van Adams. De roman werd in 1980 ook verfilmd met Richard Chamberlain in de hoofdrol.

28 Kanai, Nederland en Japan 1602-1860. 199.

29 Ibidem. 200-201.

30 Ibidem. 201

31 Kshetry, Foreigners in Japan. 55-57.

32 Goor, De Nederlandse Koloniën. 67.

33 Hunter \& Sugiyama, The History of Anglo-Japanese Relations 1600-2000. 3.; Beasley, Great Britain and the Opening of Japan 1834-1858. XV.

34 Kanai, Nederland en Japan 1602-1860. 207.

35 Kohn Goodman, Japan: The Dutch Experience. 15.

36 Blussé, 'Olifant in de porceleinkast'. 119.; Goodman, Japan and the Dutch 16001853. 12-13.; Jansen, China in the Tokugawa World. 26.; Nouët, The Shogun's City. 78.

37 Yukihiro, 'New Perspectives on the Early Tokugawa Persecution'. 53-60.; Schwentker, 'Barbaren und Lehrmeister'. 105.; Opstall, 'Japans-Nederlandse betrekkingen 1609-1856'. 10.; Clulow, The Company and the Shogun. 128.; Kohn Goodman, Japan: The Dutch Experience. 15.

38 Ibidem.; Szommer, Rugalmas hollandok. 39.

39 Parmentier \& Laarhoven, De avonturen van een VOC-soldaat. 45.

40 Kanai, Nederland en Japan 1602-1860. 208.

41 Kuipers, De VOC. 134.

42 Ibidem. 
43 Siebold, Manners and Costumes of the Japanese in the Nineteenth Century. 122.

44 Goor, De Nederlandse Koloniën. 107.

45 Kanai, Nederland en Japan 1602-1860. 211.

46 Parmentier \& Laarhoven, De avonturen van een VOC-soldaat. 46.

47 Opstall, 'Japans-Nederlandse betrekkingen 1609-1856'. 10.

48 Gaastra, De geschiedenis van de VOC. 127.

49 Kanai, Nederland en Japan 1602-1860. 213.

50 Opstall, 'Japans-Nederlandse betrekkingen 1609-1856'. 11.

51 Kanai, Nederland en Japan 1602-1860. 221.

52 Pusztai, 'Bajától Batáviáig'. 224-277.

53 Nationaal Archief, Den Haag, Nummer toegang: 1.04.02, inventarisnummer: 14225, folionummer: 235

54 Naam-Boekje Batavia, 1766. 33.

55 Naam-Boekje Batavia, 1767. 33.

56 Ibidem. 30.

57 Naam-Boekje Batavia, 1768. 29.; Pusztai, 'Bajától Batáviáig'. 224-277.

58 Naam-Boek Batavia, 1775. 28.

59 Wennekens, Gouden handel. 231.

60 Nationaal Archief, Den Haag, Nummer toegang: 1.04.02, inventarisnummer: 14225, folionummer: 235

61 Voor de volledige lijst zie: Levyssohn, Bladen over Japan. 21-23.

\section{Bibliografie}

Beasley, William G. 1995. Great Britain and the Opening of Japan 18341858. London/New York: Routledge.

Blussé, Leonard. 2005. 'Olifant in de porceleinkast, Pieter Nuyts (1598$1655)$ en zijn avonturen in het Verre Oosten.' Parmentier, Jan (red.). Noord-Zuid in Oost-Indisch perspectief. Zutphen: Walburg Pers.

Clavell, James. 1975. Shogun. London: Hodder\&Stoughton.

Clulow, Adam. 2014. The Company and the Shogun: The Dutch Encounter with Tokugawa Japan. New York: Columbia University Press. https://doi.org/10.7312/columbia/9780231164283.001.0001

Der ungarische Robinson, oder Geschichte, Abentheuer und Reisen des Andreas Jelky, eines erlernten Scheniders aus Baja: Eine wahre Begebenheit. 1827 Pesth.

Fish, Shirley. 2011. The Manila-Acapulco Galleons: The Treasure Ships of the Pacific. Bloomingon: AuthorHouse.

Gaastra, Femme S. 1991. De geschiedenis van de VOC. Zutphen: Walburgpers. 
Geissau, Anton Edlen von. 1796. Merkwürdige Aufmunterungsrede, welche Benjowsky gehalten für die Religion, den König und das Vaterland wider die Franzosen unverweilt die Waffen zu ergreifen. Wien: Sammer.

Geissau, Anton Ferdinand von. 1779. Etwas für alle zum Lesen im Frühling und Sommer: cverm. mit einem Auszuge aus der ostreichischen Geschichte und die wunderbare Geschichte des Herrn Andreas Jelky. Wien: Weingand.

Geissau, Anton von. 1805. Geschichte der Belagerung Wiens durch den König Mathias von Hungarn, in den Jahren 1484 und 1485. Wien: Strauss.

Geschichte des Herrn Andreas Jelky, eines gebohrnen Ungars, Nebst andern kurzweiligen Anekdoten. 1784 Ofen/Pressburg: Floridus Diepold Benedikt und Compag.

Geschichte des Herrn Andreas Jelky eines gebohrnen Ungars, welcher nach ausgestandenen vielen unglücklichen Zufällen, Schiffbrüchen, Sklaverey und Lebensgefahren unter den Wilden, endlich zu Batavia zu ansehnlichen Ehrenstellen gelangen ist. 1779 Wien: Johann Georg Weingand.

Goor, J. van. 1994. De Nederlandse Koloniën: Geschiedenis van de Nederlandse expansie 1600-1975. Den Haag: SDU.

Hevesi, Lajos. 1872. Jelky András kalandjai. [Avonturen van András Jelky] Pest: Heckenast.

Hevesi, Lajos. 1904. Jelky András rendkívüli kalandjai. [Buitengewone avonturen van András Jelky] Budapest: Franklin.

Hevesi, Lajos. 1955. Jelky András kalandjai. [Avonturen van András Jelky] Budapest: Móra.

Hevesi, Lajos. 1961. Die Abenteuer des András Jelky in drei Erdteilen. Neu bearb. von János Czibor, übers. von József Takách, Illustration Lajos Kondor. Budapest: Corvina.

Hevesi, Lajos. 1964. Przygody Andrasza Jelky. [De avonturen van András Jelky] Warszawa: Nasza Ksiegarnia.

Hevesi, Lajos. 1968. Abenteuer in drei Erdteilen. Gekürzte Auflage, neubearb. Von János Czibor; übers. von József Takách. Berlin: Kultur und Vortschritt.

Hevesi, Lajos. 1969. De avonturen van Andras Jelky in drie werelddelen. Vertaald door Sylvia Moor \& W. Visser. Amsterdam: Arbo. 
Hevesi, Lajos. 1985. Dobrodružstvi Andráse Jelkyho. [De avonturen van András Jelky] (medewerker: János Czibor, vertaald door Jan Lichtenstein, geillustreerd door Eduard Hájek), Praha: Albatros.

Hevesi, Ludwig. 1879. Des Schneidergesellen Andreas Jelky Abenteuer in vier Welttheilen. 2. Aufl. Budapest: Franklin.

Hevésy, Ludvig. s.d. [190?]. Räätälinkisälli Andreas Jelky’n merkilliset elämänvaiheet neljässä maanosassa. [De wonderbaarlijke avonturen van András Jelky in vier werelddelen] Vertaald door Samuli S. Helsinki: Kustannusosakeyhtaö Kirja.

Hunter, J. \& Sugiyama, S. (eds.) 2002. The History of Anglo-Japanese Relations 1600-2000. IV. Pelgrave Macmillan. https://doi.org/10.1057/9781403919526

Jansen, Marius B. 1992. China in the Tokugawa World. Cambridge, Massachusetts, London: Harvard University Press. https://doi.org/10.4159/harvard.9780674184763

K. Goodman, Grant. 2000. Japan and the Dutch 1600-1853. Richmond: Curzon.

Kanai, M. 1976. 'Nederland en Japan 1602-1860.' Meilink-Roelofsz, M.A.P. (red.) De VOC in Azië. Bussum: Fibula-Van Dishoeck.

Kohn Goodman, Grant. 2012. Japan: The Dutch Experience. London/ New Delhi/New York/Sydney: Bloomsbury.

Kolumbusz, Kristóf. 1991. Kolumbusz útinaplója. [Het dagboek van Columbus] Budapest: Akadémia.

Konrády, L. \& Povázsay, L. 1947. Jelky András viszontagságai. [De avonturen van András Jelky]. Budapest: Légrády.

Kshetry, Gopal. 2008. Foreigners in Japan: A Historical Perspective. Bloomington: Xlibris.

Kubassek, János. 2014. 'A világjáró szabólegény.' [De kleermakersgezel rond de wereld] Kubassek, János (red.) Magyarok a Föld körül. Felfedezők, utazók, tudós kalandozók. [Hongaren in de wereld. Ontdekkingsreizigers, wetenschappers]. Budapest: Kossuth.

Kuipers, Jan J. B. 2014. De VOC. Een multinational onder zeil 16021799. Zutphen: Walburg Pers.

Laver, Michael S. 2011. The Sakoku Edicts and the Politics of Tokugawa Hegemony. Amherts, New York: Cambria Press.

Levyssohn, J. H. 1852. Bladen over Japan. 's Gravenhage: Belinvante.

Murdoch, James. 1903. A History of Japan. Kobe: Cronicle. 
Naam-Boekje Batavia. 1766 Amsterdam: Petrus Schouten, Reinier Otten. Naam-Boekje Batavia. 1767 Amsterdam: Petrus Schouten, Reinier Otten. Naam-Boekje Batavia. 1768 Amsterdam: Petrus Schouten, Reinier Otten. Naam-Boek Batavia. 1775 Batavia: Egbert Heemen.

Newsom Crossley, John. 2016. The Desmarinases: Early Governors of the Spanish Philippines. London/New York: Routledge. https://doi.org/10.4324/9781315615295

Nouët, Noël. 1990. The Shogun's City. London/New York: Routledge Curzon.

Opstall, Margot E. van. 1983. 'Japans-Nederlandse betrekkingen 16091856'. Opstall, Margot E. van (red.) Vier eeuwen Nederland-Japan. Lochem: De Tijdstroom.

Parmentier, Jan \& Laarhoven, Ruudje (red.). 2002. De avonturen van een VOC-soldaat. Zutphen: Walburg Pers.

Polo, Marco. 2003. Marco Polo utazásai. [De reizen van Marco Polo] Budapest: Osiris.

Pusztai, Gábor \& Teszelszky, Kees. 2016. 'In de dienst van de VOC. Een voorlopige inventarisatie van Hongaren in dienst van de Verenigde Oost-Indische Compagnie (1602-1795).' Tropisch avontuur. Acta Neerlandica. 16.12: 25-108.

Pusztai, Gábor. 2015. 'Een Hongaarse VOC-dienaar'. Gosker, M. \& Monok, I. (red.) Peregrinus sum. Budapest/Amsterdam. 161-232.

Pusztai, Gábor. 2014. 'Bajától Batáviáig. Jelky András a Holland Keletindiai Társaság szolgálatában.' [Van Baja tot Batavia. Anrás Jelky in de dienst van de VOC] Bozzay, Réka (red). Történetek a mélyföldröl. Magyarország és Németalföld kapcsolata a kora újkorban. [Verhalen over de Lage Landen. Hongaars-Nederlandse contacten in de vroegmoderne tijd] Debrecen: Printart-Press Kft., 524-576.

Sándor, István. 1791. Jelki Andrásnak, egy született magyarnak történetei. A' ki, minek utána sok szerentsétlen eseteken, hajó töréseken, raboskodáson, és a'vad emberek között életének külömbféle veszedelmein által ment vólna, végtére Batáviában nevezetes tisztségekre hágott. [De geschiedenis van András Jelky, een geboren Hongaar. Na vele ongelukken, schipbreuken, gevangenschap, gevaren onder wilde mensen, kreeg hij in Batavia een hoge baan] Győr: Steibig József.

Schwentker, Wolfgang. 1997. 'Barbaren und Lehrmeister: Formen fremdkultureller Wahrnehmung im Japan des 19. Jahrhunderts’ Auch, Eva- 
Maria \& Förster, Stig (Hrsg.) „Barbaren” und „Weisse Teufel”. Paderborn/München/Wien/Zürich: Schöningh.

Siebold, Philipp Franz von. 1852. Manners and Costumes of the Japanese in the Nineteenth Centuty. London: Murray.

Solymos, Ede. 1957. Jelky András a hiteles adatok fényénél. [András Jelky en de betrouwbare bronnen] Baja: A Bajai Türr István Múzeum Kiadványai (1).

Solymos, Ede. 1983. Ki volt Jelky András? [Wie was András Jelky?] Baja: A bajai Türr István Múzeum kiadványai (25).

Szommer, Gábor. 2017. 'Rugalmas hollandok.' [Flexibele Nederlanders] BBC History 7.9: 39.

Túróczi, Tamás. 2017. "Szamurájok és „déli barbárok” [Samoerai en 'zuidelijke barbaren'] BBC History. 7,9:39.

Wennekens, Wim. 2008. Gouden handel: De eerste Nederlanders overzee en wat ze daar haalden. Amsterdam: Olympos.

Wunderbare Reise-Geschichte des Hrn. Andreas Jelky eines gebohrnen Ungars, welcher als Schneidergeselle in die Fremde gereiset, nach ausgestandenen vielen unglücklichen Zufällen, Schiffbrüchen, Sklaverey und Lebensgefahren unter den Wilden, endlich zu Batavia in Indien $z u$ ansehnlichen Ehrenstellen gelanget und anjetzo wirklich in Wien sich befindet, allwo er die allerhöchste Gnade gehabt, beyden Kaiserl. Majstäten seine Geschichte zu erzählen, und von allerhöchst Denenselben beschenkt zu werden. 1779 Prag: Johann Ferdinand Edlen von Schönfeld.

Yukihiro, Ohashi. 1996. 'New Perspectives on the Early Tokugawa Persecution' Breen, John \& Williams, Mark (eds.) Japan and Christianity: Inpacts and Responses. London: Macmillan. 53-60. https://doi.org/10.1007/978-1-349-24360-0_4

\section{Archiefbronnen}

Nationaal Archief, Den Haag, Nummer toegang: 1.04.02, inventtarisnummer: 14225, folionummer: 235

Nationaal Archief, Den Haag, Nummer toegang: 1.04.02, inventarisnummer: 14225, folionummer: 235 


\section{Aanhangsel \\ $* * *$ \\ GESCHIEDENIS VAN DE HEER ANDREAS JELKY \\ een geboren Hongaar,}

die na veel rampen en ongelukken, schipbreuken en gevangenschap, slavernij en gevaren onder de wilden, uiteindelijk in Batavia een eervolle baan kreeg.

WIEN

Johan Georg Weingand, 1779.

[3]

De vader van Andreas Jelky diende als soldaat onder de keizers Leopold, Jozef en Karel. ${ }^{1}$ Hij was bij de laatste herovering van Belgrado ${ }^{2}$ aanwezig. Na zijn ontslag uit militaire dienst vestigde hij zich in de Hongaarse stad Baja. Hier werkte hij met zijn drie zoons als kleermaker. De oudste van de zonen maakte in de keizerlijke hoofdstad Wenen carrière en mettertijd werd hij keizerlijke en koninklijke kleermaker. Vervolgens haalde hij zijn broer Andreas naar Wenen om bij hem als kleermaker te werken. Zodra Andreas voldoende over dit beroep had geleerd, raadde zijn broer hem aan naar Parijs te gaan om zich daar verder te ontwikkelen. Andreas luisterde naar de raadgeving van zijn broer en vertrok op 13 maart 1754 van Wenen naar Praag. Van daar ging hij naar Dresden, Leipzig en Neurenberg, om uiteindelijk in Erlangen aan te komen. Hij verbleef hier twee maanden en begon er zijn beroep uit te oefenen. Zijn broer, die van dit oponthoud hoorde, spoorde hem aan

[4]

zijn reis richting Parijs voort te zetten. Andreas ging dus weer op reis en kwam in Aschaffenburg aan. In die tijd was er in het Heilige Roomse Rijk een groot gebrek aan soldaten en het scheelde maar weinig of ook hij werd geronseld. Hij kon dit lot slechts door een list ontkomen. Een boerin 
smokkelde hem in een mand op haar rug de stad uit, waarvoor hij haar één gulden betaalde. Nauwelijks was hij dit gevaar ontkomen, of hij raakte meteen in een ander verwikkeld. In Hanau, bij de stadpoort, werd zijn reispaspoort, dat hij de schildwacht toonde, in stukken gescheurd. Jelky werd door de soldaten naar de kazerne gebracht, waar hij samen met andere geronselde jongens naar Hannover zou worden overgebracht. Toen ze bij de Main kwamen, moesten de soldaten worden ingescheept, maar een deel van de manschappen, waaronder Jelky, moest worden achtergelaten omdat ze niet allemaal in het schip pasten. Ze moesten wachten tot het schip zou terugkeren. Jelky en een andere geronselde soldaat uit Bohemen maakten van de gelegenheid gebruik en slopen in het holst van de nacht het kamp uit en kozen het hazenpad. Na veel omzwervingen kwam hij aan in Bonn, waar hij een paspoort kreeg, waarmee hij doorreisde naar Nijmegen. Hier ontmoette hij een Hessenaar die hem vertelde dat hij van plan was naar Rotterdam te gaan, waar hij naast een neef ook veel goede kennissen had die Jelky aan een schip zouden kunnen helpen, dat naar Frankrijk zou varen. Jelky sloot zich dus bij de Hessenaar aan

en zo kwamen ze aan in Rotterdam. In een herberg werden ze door de herbergier, die de Hessenaar zijn neef noemde, op vorstelijke wijze onthaald.

$\mathrm{Na}$ vier dagen was de Hessenaar echter verdwenen en werd Jelky door de herbergier de rekening van 50 daalders gepresenteerd. Jelky protesteerde tevergeefs dat hij in de maling was genomen en toonde de herbergier zijn lege beurs, maar dat hielp allemaal niet. Hij moest dienst nemen als soldaat. Hij werd in uniform gestoken, kreeg een maandloon van 9 gulden en werd samen met 80 Duitsers en vele Nederlanders op een schip gezet dat klaarlag om naar Oost-Indië te vertrekken. Op 30 oktober 1775 vertrok het schip. Eén dag later, toen ze in het Kanaal voeren tussen Frankrijk en Engeland, trokken zich, na enige uren windstilte, aan de hemel donkere wolken samen en brak er plots een wilde storm los. Het bliksemde en donderde enorm en de bliksem sloeg in op het schip waarop er brand ontstond. De opvarenden waren enorm geschrokken en verloren de moed. De schipper gaf bevelen, probeerde de manschappen moed in te spreken en trachtte hen te overtuigen dat ze niet in paniek moesten raken. Sommigen wilden echter niet luisteren en gooiden zich in blinde paniek 
overboord, zich vastklampend aan balken of planken. Ook Jelky pakte een balk beet en stortte zich in het water.

[6]

De hele nacht dreef hij in zee en zijn ledematen werden door de kou zo stijf dat hij de balk niet meer kon loslaten, hoewel hij dat graag had gedaan omdat hij al alle hoop op redding had opgegeven. De volgende dag, toen de storm ging liggen, werd hij samen met vele anderen door Engelse vissers uit het water gehaald. Eén van de vissers bood Jelky in zijn huis onderdak en verzorgde hem zo goed dat hij binnen korte tijd weer op krachten was gekomen. Als blijk van dank herstelde Jelky de kleren van de visser en zijn familieleden. Hij ging echter vaak naar het strand om naar een schip uit te kijken, waarmee hij weer de zee op kon. Uiteindelijk kwam zijn wens uit toen er een ander Nederlands schip, door onweer gedreven, aan de kust verscheen. Jelky ging terstond naar de schipper, vertelde zijn verhaal en vroeg of hij mee mocht varen. De schipper stond het toe, op voorwaarde dat Jelky onderweg de kleren van de matrozen zou herstellen. De eindbestemming van het schip was Suriname, een Nederlandse kolonie in Amerika. Na enkele weken kwamen ze daar inderdaad in de haven aan. Hier laadden ze tabak en andere handelswaren in en voeren weer terug, maar onderweg werd het schip door een grote storm zo beschadigd, dat de schipper dringende reparaties noodzakelijk vond. Daarom deden ze in februari 1756 de haven van Lissabon aan.

Hier kon Jelky de ruïnes en overblijfselen van de hoofdstad van Portugal zien, die op 1 november 1755 door een verschrikkelijke aardbeving was verwoest. Jelky vroeg aan de schipper zijn loon voor het werk dat hij onderweg verricht had, maar ontving als antwoord dat hij blij moest wezen dat hij aan boord eten kreeg. Hierdoor raakte hij in zeer diepe armoede en hij liep de hele haven rond en informeerde naar de aankomst en het vertrek van de schepen. Uiteindelijk hoorde hij dat in de komende dagen twee Maltese schepen naar Azië zouden vertrekken en na de nodige smeekbeden kon hij bereiken dat hij op het kleinere schip werd aangenomen. $\mathrm{Na}$ vier dagen vertrokken beide schepen bij gunstige wind. $\mathrm{Na}$ een tijdje moest het kleinere schip op bevel van de schipper naar rechts varen om uit te zoeken of er kapers in de buurt waren. Twee dagen lang 
waren ze op verkenning, maar ze vonden niets. Ze waren reeds op de terugweg toen de stuurman opeens riep dat hij een afschrikwekkend schip vergezeld van twee kleinere schepen had gezien. De schipper had meteen in de gaten dat het zeerovers waren en beval snel er vandoor te gaan. Maar er kwam opeens een sterke wind op, waardoor de grote mast brak. Van vluchten was geen sprake meer, dus men greep de wapens. Maar de Turkse kapers omsingelden het schip en vielen het van alle kanten aan.

Ze veroverden het schip met geweld. De opvarenden die weerstand boden werden neergesabeld, de rest, waaronder Jelky, werd gevangengenomen. De kapers verdeelden onder elkaar de buit, de voorraden, het gereedschap en ook de gevangenen. Jelky werd naar het kleinere schip overgebracht. Op dit schip waren vierentwintig roeibanken, met twaalf roeiers op elke bank. Op dit schip roeide hij zeven weken, waarna hij aan land werd gebracht. Maar waar hij zich bevond wist hij niet omdat hij geen Turks sprak, en de naam van het land was voor hem een raadsel. Samen met de andere gevangenen werd hij naar een grote stad gebracht en op de markt te koop aangeboden. Men wilde voor hem een iets hogere prijs krijgen dan voor de anderen, daarom wilde niemand hem kopen. De kapers keken namelijk naar de handen van de gevangenen om de prijs vast te stellen. De lui die eelt op hun handen hadden, werden voor een lagere prijs verkocht omdat ze van lagere komaf zouden zijn. Maar de mensen die een zachte huid hadden, waren volgens hen van goeden huize, dus voor hen werd een hogere prijs gevraagd. Daarom werd Jelky naar een andere zeehaven, naar Bachna, overgebracht en aan een Turkse edelman verkocht. Deze Turk was vroeger ook kaper geweest, maar omdat hij al oud was, leidde hij een rustig leven aan land. Jelky werd dus slaaf in het huis van deze Turkse edelman. Maar de Turk, zijn meester, was zo goedmoedig en welwillend tegenover Jelky dat hij drie maanden lang nauwelijks de last van zijn slavenbestaan zou voelen.

[9]

Toch ging de opzichter, een grove en harde man, met Jelky, net als met de andere slaven, uitermate gruwelijk om. De meester voer bijna elke week naar één van de eilandjes in de buurt, waar hij zich met het vangen van vis vermaakte. Jelky moest hem bij deze gelegenheden begeleiden. Op een 
dag beval de Turkse edelman, de baas van Jelky dat een fregat moest worden uitgerust en van proviand, rijst, koffie, water en andere levensmiddelen voor enkele dagen moest worden voorzien. Tegen de avond, toen men op het punt stond te vertrekken, kregen ze bericht dat een Turkse edelman uit de omgeving zich de volgende dag bij hun meester zou aanmelden. Hij zou op bezoek komen en ook blijven eten. De opzichter moest dus alleen met Jelky en een jongen uitvaren om vissen te vangen voor het diner van de volgende dag. Toen ze al ver weg van de kust lagen, gaf de opzichter bevel de zeilen te hijsen en begon onmiddellijk hierop zonder enige reden Jelky te slaan. Vervolgens haalde de opzichter de zeilen weer neer, waarbij hij met zijn bovenlijf buiten het schip hing. Toen Jelky dit zag, wist hij dat hij deze kans niet moest laten varen. Hij pakte de opzichter bij de voeten, tilde hem op en gooide hem zo in de zee. De opzichter vocht enige tijd met de golven, maar uiteindelijk zwom hij naar het schip. Hij was immers een uitstekende zwemmer.

Jelky echter pakte een mes en zei de opzichter dat hij hem in zijn handen zou steken als hij zich aan het schip zou vasthouden. Daarop verwijderde de opzichter zich van het schip en zwom naar het strand. De jongen op het schip dacht dat hij vervolgens aan de beurt zou zijn, viel neer voor de voeten van Jelky en beloofde hem trouwe dienst. Hierop beloofde Jelky de jongen veiligheid en gaf hij zijn fregat aan de gunstige wind over. Zeven dagen en zeven nachten zeilden ze bij gelijkmatige wind, waarbij ze elkaar afwisselden bij het slapen en waken. Op de achtste dag zagen ze een groot schip. Jelky meende dat het een kaperschip was en schrok zich te pletter, maar toen het schip dichterbij kwam, bleek het een christelijk schip te zijn. Alle twee hieven de handen omhoog en smeekten om hulp. Vanaf het schip maakte men met gebaren duidelijk dat ze dichterbij moesten komen. Ze zeilden naar het grote schip en werden aan boord genomen. Jelky werd ingedeeld bij de matrozen. Het was een Portugees koopvaardijschip, onderweg naar Macau. Na enkele maanden varen, in juni 1757, liep het schip gelukkig de haven van Macau binnen. Deze stad, aan de uiterste grens van China is Portugees bezit met belangrijke handelsactiviteiten. Hier bedankte Jelky de schipper voor zijn redding en hij kreeg toestemming te gaan waarheen hij maar wilde. Bovendien ontving hij 
tachtig Spaanse matten ${ }^{3}$ in contanten voor het fregat. In dezelfde haven lag een Chinees schip dat naar Kanton, een belangrijke stad in het Chinese Rijk, zou varen. Jelky sprak met de Chinese schipper af dat hij voor achttien Spaanse matten mee mocht naar Kanton. Er restte alleen nog de zaak met de Turkse jongen, die huilde en Jelky vroeg hem niet in de steek te laten, maar de Chinezen weigerden hem op het schip mee te nemen. Jelky verkocht de jongen dus aan de Portugezen voor zestig Spaanse matten. In Kanton aangekomen ging Jelky naar de Nederlandse consul, de heer De Vint. Hij vertelde zijn verhaal en nam dienst bij de Nederlandse troepen. In november van hetzelfde jaar vertrok hij met een Nederlands schip, de Justitia, naar Batavia. Deze stad ligt op Java en is de grootste en belangrijkste van alle Nederlandse nederzettingen in OostIndië. In januari $1758 \mathrm{kwam}$ hij in Batavia aan en diende er twee maanden als soldaat. Na deze tijd vernam een van de machtigste mannen van de Verenigde Oostindische Compagnie, Petrus Albertus van der Parra, ${ }^{4}$ dat Jelky kleermaker was. Vervolgens bood Van der Parra Jelky onderdak omdat hij wilde dat Jelky voor hem zou werken. Dat liep goed, zo goed zelfs dat Jelky nog in hetzelfde jaar vrijburger van de stad werd. Jelky trouwde met de dochter van een Engelse landpachter, Sequin, omdat hij door dit huwelijk zijn positie hoopte te verbeteren.

Maar dat pakte niet zo gunstig uit als hij hoopte. Zijn schoonvader weigerde hem alle hulp, ondanks zijn miserabele situatie. Maar dat was niet de enige tegenslag die hij had te verduren. Hij kreeg een opdracht om een fluwelen bruidsjurk voor een edele dame te maken. Hiervoor nam hij enkelen inlanders in dienst en werkte hij tot diep in de nacht door. Maar één van de inlanders stootte per toeval de lamp om, en de olie kwam op de jurk terecht. Jelky was diep ongelukkig en ging vroeg in de ochtend naar het VOC pakhuis om een stuk fluweel van negen ellen ${ }^{5}$ lang uit te zoeken. In het register van het pakhuis liet hij de naam van Van der Parra vermelden. De jurk was op tijd klaar en de volgende dag vond Jelky geld om het geleende fluweel te betalen. Aan het einde van de maand werden de rekeningen voor alles wat hij en zijn familie uit het pakhuis hadden gebruikt zoals gewoonlijk aan Van der Parra gepresenteerd. De vrouw van Van der Parra ontdekte de zaak met het fluweel en werd erg boos, 
hoewel de rekening al vereffend was. Zij meldde de kwestie meteen aan haar man. De schuldige werd opgespoord, Jelky wierp zich voor de voeten van Van der Parra, vertelde het trieste verhaal met de olielamp en vroeg om vergiffenis. Maar de woede van de vrouw was niet te temperen. Jelky was in ongenade gevallen en Van der Parra gaf het bevel dat Jelky weer dienst moest nemen als soldaat. De volgende dag vertrok hij al met een schip naar Crylan ${ }^{6}$ waar de Hollanders weer met de koning van Candy in oorlog waren. ${ }^{7}$

Maar omdat Jelky een burger was, kreeg hij de rang van sergeant, met een maandloon van vierentwintig gulden. ${ }^{8}$ Op die dag in begin 1760 vertrouwde Jelky zijn vrouw aan de hoede van zijn schoonvader toe en vertrok samen met een groep soldaten inderdaad uit Batavia. Drie maanden lang zat hij in het kamp op Crylan. Daarna kreeg hij de order van de bevelhebbende generaal van het eiland dat hij met een groep militairen een met kaneel geladen schip dat naar Batavia zou vertrekken naar het eiland Banda moest begeleiden. Op Banda aangekomen, kreeg hij het bevel een ander schip dat met nootmuskaat en andere handelswaar geladen was, naar Ambon te begeleiden. Daar stapte hij op een schip dat kruidnagels naar het eiland Ternate vervoerde, waar de Nederlanders enkele forten hadden. Hier werd Jelky bij de militairen ingedeeld die de vesting bewaakten. De Nederlanders kregen elk jaar van de koningen van de eilanden Ternate, Molyr, Machiam en Gilolo genaamd, een enorme hoeveelheid kruidnagels, waarmee zij vanwege hun monopolie een zeer voordelige handel konden drijven. Men zag dat er met de dag steeds meer kruidnagelbomen bijkwamen, en de Nederlanders vreesden dat in de toekomst ook andere landen hiervan hun deel zouden kunnen opeisen. Daarom sloten de Hollanders een verdrag met de koningen dat de overtollige kruidnagelbomen moesten worden omgehakt. Voor elke gevelde boom

betaalden de Nederlanders twaalf gulden. Om de uitvoering van deze overeenkomst te controleren, moest Jelky met vierentwintig Nederlanders en met 140 Moren $^{9}$ er heen varen. Vanwege de onervarenheid van de gids kwamen ze echter in het grensgebied van de naburige heidense koning 
terecht. Dit gebied van de zwarten werd Papoea genoemd. Een heleboel Papoea's verzamelden zich en vielen de groep van Jelky aan. Zijn inheemse soldaten, die veel beter konden rennen dan de Europeanen, namen de benen in de doornige struiken, maar de meeste Nederlanders werden gedood. Negen van hen werden gevangengenomen en meteen van elkaar afgezonderd. Jelky, die zich ook onder de gevangenen bevond, werd aan één van de voornaamste bewoners overgeleverd en in een gevangenis gestopt die eerder op een kooi leek. De volgende dag werd hij door de zestienjarige dochter van deze belangrijke inlander bezocht. Zij bekeek Jelky grondig en scheen zeer begaan te zijn met zijn lot. Door gebaren legde zij aan hem uit dat hij binnenkort in stukken zou worden gesneden en opgegeten. Jelky viel op zijn knieën en vroeg om medelijden. De jonge vrouw gaf te kennen dat zij hem wel wilde helpen, indien Jelky geneigd was een tegenprestatie te leveren. Hierop zwoer Jelky haar eeuwige liefde en grote dankbaarheid. Op de negende dag bezocht de zwarte jonge vrouw hem opnieuw om hem te troosten en hem te verzekeren dat er

later hulp zou komen. Om middernacht zag hij dat de deur van zijn cel niet meer op slot was en de vrouw kwam met twee inheemsen binnen. De vrouw pakte Jelky's hand en leidde hem over een smal pad door het bos naar een rivier. Hier stapten ze in een bootje en voeren stroomafwaarts met de rivier mee waarbij de twee inlanders roeiden. Ze waren al een behoorlijk eind gekomen en niet meer ver van de zee, toen ze een moerassig gebied in gingen, waar ze in een meertje met laag water terechtkwamen. Jelky en de vrouw waadden door het lage water, de twee inheemsen trokken het bootje mee en richtten het neergebogen riet achter zich weer op om de sporen van hun vluchtweg te wissen. Ze kwamen uiteindelijk in een verlaten en onvruchtbaar gebied aan waar ze ver van iedereen dertien maanden doorbrachten. Een van takken gemaakte kleine hut was hun woning. De twee inheemsen, die hen op de vlucht ook hadden begeleid, dienden hen ook hier trouw. Kokosnoten, paradijsvijgen, ${ }^{10}$ vissen, kreeften en schildpadden waren hun voeding. Jelky leed de hele tijd aan een psychische kwaal die uiteindelijk ook zijn fysieke vermogen aantastte. De trouwe vrouw probeerde hem zo veel mogelijk troost te bieden: was hij vrolijk, dan lachte ze, was hij treurig, dan huilde ze. In de dertiende maand van hun verblijf stierf ze zelf aan een ziekte, waarvan noch Jelky, noch de twee inheemsen haar 
konden genezen. De zwarten probeerden Jelky te troosten en vroegen hem of ze van het dode lichaam van de vrouw wellicht een gerecht zouden toebereiden. Maar Jelky bad voor haar en begroef haar lichaam. De inheemsen dienden hem nog steeds, maar Jelky besloot het woeste gebied te verlaten en keek steeds uit naar een schip. Op de vijfde dag zag hij een Chinees schip in de verte, dat van Ternate naar Batavia voer. Hij maakte de lange bladeren van een pisangboom aan een stok vast en zwaaide ermee totdat de Chinezen hem zagen. Ze stuurden een bootje naar hem toe en brachten hem samen met de twee inheemsen aan boord. Met dit schip kwam Jelky in Batavia aan waarop hij meteen naar het Waterkasteel $^{11}$ ging en vroeg om een militair uniform. Hier hoorde hij dat de opperste bestuurder van de stad, de heer Messel, ${ }^{12}$ reeds was overleden, en dat zijn opvolger één van de voormalige leiders van de Oost-Indische Compagnie, de heer Van der Parra, was. Jelky ging dus onmiddellijk naar de gouverneur en wierp zich voor de voeten van de man. Van der Parra herkende Jelky onmiddellijk, herinnerde zich zijn veel te streng gedrag tegenover hem en bleef lang onbeweeglijk zitten. Uiteindelijk wendde hij zijn gezicht af en weende bitter.

\section{[17]}

De gouverneur luisterde naar Jelky's verhaal, voelde zich schuldig aan zijn lot en gaf hem een geschreven bewijs dat Jelky op Nederlands gebied onder zijn bescherming stond. Van der Parra troostte hem en beloofde hem alles goed te maken wat hem was overkomen. Opgelucht door deze belofte begaf Jelky zich ijlings naar zijn schoonvader en omarmde zijn echtgenote en zijn dochtertje. Vervolgens stuurde de gouverneur hem veel flessen wijn, driehonderd flessen bier en vijfhonderd daalders ${ }^{13}$ om hiermee de nodige huisraad aan te schaffen en weer op krachten te komen. Vanaf deze tijd toonde de gouverneur zich tegenover hem zeer welwillend en vaderlijk. Eerst ontving hij de rang van vaandrig in de burgerwacht en daarna werd Jelky tot voogd van alle mohammedaanse en heidense weeskinderen benoemd. ${ }^{14}$ Hierdoor werd hem de opvoeding en het beheer van het vermogen van alle inheemse en Chinese kinderen toevertrouwd. Zijn weldoener stond hem ook toe twaalf huurrijtuigen te houden en deze te verhuren. Bovendien schoot de gouverneur Jelky het geld voor dat nodig was om deze wagens aan te schaffen met daarnaast de paarden, 
zestig knechten en andere benodigdheden. Hierdoor maakte Jelky aanzienlijke winsten en werd een rijk man

omdat hij de verkregen rechten aan anderen met een groot voordeel verkocht. De gouverneur verleende bovendien nog meer gunsten aan Jelky. Hij mocht uit de kas van de gouverneur naar zijn eigen goeddunken onbeperkt geld lenen zonder rente. Alleen het geleende bedrag, het kapitaal moest hij terugbetalen, zonder opslag. Hierdoor verwierf hij zich binnen enkele jaren zo'n enorm vermogen dat hij een landgoed met veertienduizend huizen kocht. Door zijn zachte aard was hij door iedereen geliefd, of het nu mohammedanen of andere heidenen waren. Hij werd hierna kapitein-luitenant van de burgerij, lid van het stadbestuur en geheimraad van de Nederlandse gouverneurs. In deze positie moest hij de belangrijkste zaken van de Oost-Indische Compagnie en de Republiek der Zeven Verenigde Nederlanden behartigen. Zijn eerste belangrijkste opdracht was zijn gezantschap naar Japan, waar het hem dankzij kostbare geschenken lukte de belangen van de Republiek te behartigen. Een andere opdracht was om naar Banta, ${ }^{15}$ de hoofdstad van een groot rijk op het eiland Java, te gaan om de zoon van de reeds zeer oude koning te kronen die zelf de Republiek gevraagd had de prins zijn plaats te laten innemen. De koning was voor die tijd onafhankelijk, maar in 1683 veroverden de Nederlanders zijn gebied ${ }^{16}$ en

sindsdien zat hij in zijn koninklijke paleis opgesloten. Na de ceremonie kreeg Jelky van de oude koning een buitengewoon rijkversierde tabaksdoos cadeau, die in Wenen door velen gezien en bewonderd werd. Later werd Jelky opgedragen samen met enkele ingenieurs een geschikte plaats te vinden voor een fort op het eiland Palumba, dat in de inheemse taal Flamba heet. Hier had Jelky de gelegenheid een zeer bijzonder gebeuren te zien: de koning van dit eiland was net overleden en hij liet tachtig echtgenotes achter die volgens de traditie van dit volk na de dood van de koning allemaal verbrand moesten worden. De reden van deze traditie is het volgende: vroeger werden door de vrouwen van de koning zo veel opstanden aangesticht dat bijna geen enkele koning een natuurlijke dood was gestorven. Daarom werd door de wet bepaald dat in de toekomst de 
koning alleen door een feestelijk verdrag met een vrouw kon trouwen, waarin werd bepaald dat zij na de dood van de koning ook moest sterven. Sinds die tijd was geen enkele koning meer overleden door gewelddadigheden, omdat het in het eigen belang van de vrouwen was het leven van de koning zo lang mogelijk te rekken. Deze treurige gebeurtenis waarbij Jelky aanwezig was, werd met pracht en praal uitgevoerd.

Onmiddellijk na de dood van de koning verzamelde zich een enorme menigte uit het hele land, waaronder ook de familie van de vrouwen van de koning, in de hoofdstad. Op de voorbestemde dag gingen de vrouwen, opgesmukt met gouden sieraden en edelstenen, in lange rijen naar de tempel. Naast elke vrouw liep een priester met een witte duif in de ene en met een dolk in de andere hand. Als de stoet bij een bepaalde plek kwam, stopten ze en de vrouwen namen afscheid van hun familie. De vrouwen deelden hun sieraden uit onder de familieleden bij wijze van afscheid. Daarna namen ze de witte duif van de priesters over en lieten die wegvliegen, terwijl ze deze woorden spraken: "Net als deze duif in de vrije lucht vliegt, verlang ik ernaar bij mijn echtgenoot de koning te zijn." Zodra deze woorden werden uitgesproken, stak de begeleidende afgodspriester de dolk in het hart van de vrouw naast hem. Nadat alle vrouwen op deze manier gedood waren, legde men de lichamen op de brandstapel en werden ze verbrand.

De gelukkige tijd van Jelky werd onderbroken door treurige gebeurtenissen die in het leven van elk mens voorkomen. Zijn echtgenote, met wie hij twee dochters had die nog steeds in leven zijn, overleed in 1772. Deze wond was nog niet helemaal geheeld toen de gouverneur, zijn weldoener, op 28 december 1775 stierf.

Vanaf die tijd verviel Jelky in een duistere zielstoestand die ook zijn uitwerking had op zijn algemene lichamelijke conditie. Hij werd zo zwak dat velen aan zijn herstel twijfelden. Bovendien verlangde hij er steeds meer naar nog eenmaal zijn vaderland en zijn familie te zien. Zijn dochters en zijn vrienden zagen dit verlangen en rieden hem aan dit plan uit te voeren. Jelky regelde hierop zijn zaken, vertrouwde zijn dochters aan zijn buren toe die goed voor hen zouden zorgen en vertrok met de twee Moren die 
hij nog uit Pagous had meegenomen en in zijn huis had opgenomen, op 25 oktober 1776 met het schip Gokendorf ${ }^{17}$ uit Batavia. Hij kwam op 31 december van hetzelfde jaar aan bij Kaap de Goede Hoop, waar hij en de twee Moren erg ziek werden. De laatste twee bezweken aan de ziekte, maar Jelky knapte zienderogen op. Hij zette zijn reis met het schip Serres ${ }^{18}$ voort, dat uit China was vertrokken en waarvan de schipper de neef van zijn vrouw was. Met dit schip vertrok hij op 6 mei 1777 van de Kaap en arriveerde in Amsterdam op 30 augustus.

Van daar ging hij naar Engeland, om zijn schoonvader te bezoeken, die reeds in 1762 van Batavia naar zijn vaderland was teruggekeerd. Na een tijdje keerde hij weer naar Amsterdam terug en van daar reisde hij door naar Wenen, waar hij op 2 oktober van het afgelopen jaar ${ }^{19}$ aankwam. Hij ging in het huis van zijn broer wonen waar hij zich nog steeds bevindt. In Wenen vond hij de allerhoogste genade om voor de twee koninklijke hoogheden ${ }^{20}$ te mogen verschijnen en hier mocht hij zijn levensverhaal vertellen. Bij deze gelegenheid legde hij enkele rariteiten uit Indië voor de voeten van de koninklijke hoogheden, waarop hij een gouden penning en een gouden tabaksdoos cadeau kreeg.

Vertaald door Gábor Pusztai ${ }^{21}$

Noten

1 Bedoeld worden de keizers van het huis Habsburg van het Heilige Roomse Rijk. Keizer Leopold I (1640-1705) vanaf 1655 koning van Hongarije, vanaf 1658 keizer. Keizer Jozef I (regeerde van 1705 tot1711) en Karel VI (regeerde van 1711 tot1740) ook koning van Hongarije onder de naam Karel III.

2 De herovering van Belgrado op de Turken op 16 augustus 1717. De keizerlijke troepen werden door Eugen von Savoy aangevoerd.

3 Spaanse mat: peso, een zilvermunt van 8 real.

4 Petrus Albertus van der Parra (Colombo, 29 september 1714 - Weltevreden, 28 december 1775). Van der Parra makte carriére in de kolonie. Hij was vanaf 1751 lid van Raad van Indië, vanaf 1752 president van het College van Heemraden, vanaf 1755 directeur-generaal van de VOC, vanaf 1761 Gouverneur-Genaraal. Zijn opvolger als Gouverneur Generaal werd in 1775 Jeremias van Riemsdijk (17121777). 
5 Een el is een oude lengtemaat van ca. $70 \mathrm{~cm}$.

6 Ceylon.

7 Het gaat waarschijnlijk om de opstand op Ceylon. De koning van Candy vocht tegen de VOC-troepen tussen 1760 en 1766.

8 Nu zou dat $€ 231$,- waard zijn.

9 Met Moren wordt hier waarschijnlijk inlanders bedoeld.

10 Paradijsvijgen (Musa paradisiaca), ofwel bananen.

11 Het waterkasteel stond aan de westerzijde van de haven van Batavia en diende ter verdediging van de stad. Zie: Batavia: De hoofdstad van Neerlands O. Indien, Amsterdam/Haarlingen, Petrus Conradi/Volkert van der Plaats, 1782, 115.

12 Bedoeld wordt Gouverneur Generaal Jacob Mossel (Enkhuizen, 28 november 1704 Batavia, 15 mei 1761).

13 De daalder was een zilveren munt en was in die tijd 30 stuivers dus anderhalve gulden waard. 500 daalders $=$ ca. $€ 5.438$,-

14 Het ging dus om alle niet-christelijke weeskinderen van Batavia.

15 Bantam.

16 Bedoeld wordt waarschijnlijk Agong of Agoeng, de sultaan van Bantam die tussen 1651 en 1682 regeerde.

17 Een schip met de naam Gokendorf bestond niet.

18 Een schip met de naam Serres bestond evenmin.

19 Bedoeld wordt het jaar 1778.

20 Bedoeld worden hier Maria Theresia van Oostenrijk (1717-1780) keizerin van het Heilige Roomse Rijk, tevens koningin van Hongarije en haar zoon, de latere Jozef II (1741-1790).

21 Met dank aan Annyke de Jong, Michiel van Kempen, Adrienne Zuiderweg en Jaap Doedens voor hun nuttige adviezen. 